DOI https://doi.org/10.18551/rjoas.2017-09.19

\title{
TIME AND COST EFFICIENCY ANALYSIS WITH FAST TRACK METHOD ON SAMARINDA-ANGGANA ROAD IMPROVEMENT PROJECT
}

\author{
Rizaldi Muhammad Yusuf*, Hidayat Sutanto, Santosa Andrianus Agus \\ Study Program of Civil Engineering, Concentration on Construction Management \\ National Institute of Technology Malang, Indonesia \\ *E-mail: myrizaldii@gmail.com
}

\begin{abstract}
On Samarinda-Anggana Road Improvement Project, in estimating the time and cost of a project, an acceleration process is needed. Acceleration is usually done to optimize the duration of existing activities and to minimize risk but it still gets optimal results. One of the ways to achieve time and cost efficiency is by using the method of "Fast Track" with modification of CPM model scheduling on the activities of the critical path. The objectives of this research are: 1) Determining the optimal result with the Fast Track process on the project, 2) Determining the cost plan for the time acceleration, 3) Calculating the amount of time difference of optimum acceleration in the completion of road improvement project and cost caused by acceleration. This research uses fast track method. From the calculation of the project duration using fast track method, the following results are obtained: 1) road improvement project of Samarinda - Anggana calculated with the CPM model with normal duration in the contract time is 210 days, so the project needs to be accelerated by Fast Track method that produces acceleration duration to 171 days, 2) the optimum cost incurred in the normal duration or the project budget plan is Rp.16.677.156.783,43 and costs gained after Fast Track method is Rp. 16.522.297.470,44, 3) the difference in duration between normal time and after fast track is 39 days. While, the difference in cost between normal time and after using Fast Track is Rp.154.859.312,99, it can be concluded that it saves $0.93 \%$ from the normal cost.
\end{abstract}

\section{KEY WORDS}

Efficiency, fast track, project.

As the development of the industrial world goes by as well as the development of transportation facilities, especially roads that are growing rapidly, the difficulty level to manage and run a road project is much higher. The higher the difficulty level, the longer the length of time required to complete the project, (Davidson, 2002). Therefore, it is necessary to have time management which in addition to sharpen priorities, it also tries to improve the efficiency and effectiveness of project management in order to achieve maximum results from available resources, (Zhu et al, 2009). Everything is to achieve the goal of a road improvement project that is success that meets the criteria of time (schedule), as well as cost (budget) and quality, (Akbar, 2002).

In addition to time management, absolutely it also must be followed by the implementation of a good project and in accordance with its planning, (Hellriegel and Slocum, 2006). With good time management and execution, the risk of a road construction project will have a little retardation. This will directly reduce the project cost of the project, and it will ultimately provide its own advantages for contractors as responsible for project implementation. Each construction project typically has a specific implementation plan and implementation schedule: when the project should begin, when it should be completed, how it will be done, and how its resources are provided, (Carayannis et al, 2005). The common impact that often happens is the retardation in project implementation time, besides the increased cost of project implementation. The retardation of project execution generally always has adverse consequences for both owners and contractors because the impact of retardation is conflict and debate about what and who causes, as well as the demands of 
time and added costs. Therefore, it is necessary here to have a time management which in addition to sharpen the priority, it also attempts for efficiency increase.

Project implementation is confronted with three problems: cost, time, and quality, (Söderlund, 2004). These three problems can be interpreted as the targets of the project, which is defined as appropriate cost, appropriate time, and appropriate quality. The success of the project activities is tied to these three objectives, to the extent that the three elements of cost, time, and quality can be met. Time management includes the processes needed to ensure the completion time of the activity. Time management systems concern on whether or not planning and scheduling activities are running. In which in planning time scheduling activities, specific procedures have been provided to complete construction activities more quickly and efficiently. For the sake of the smooth running of a project, management is needed that will manage the project from start to the end of project, specifically project management. The field of project management grows and evolves because of the need in the modern industrial world to coordinate and control complex activities. Project management has a special nature, in which time management work is limited by a predetermined schedule.

Changes in conditions so quickly demand that each of the leaders involved in the project to anticipate the situation, as well as arrange the necessary forms of action. This can be done when there is a mature planning concept and is based on data, information, capabilities, and experience. The success or failure of the implementation is often caused by lack of project plan activities and less effective controls, resulting in inefficient project activities, resulting in retardation, declining quality of work, and increasing implementation costs. The retardation in completion of the project itself is a very undesirable condition as this can cost both parties, both in terms of time and cost. In relation to the time and cost of production, the company must be as efficient as possible in the use of time in each activity, so the cost can be minimized from the initial plan.

In the projects of roads and bridges for example, good management of work scheduling is highly needed, therefore it needs to be handled with careful calculations. A project is considered good if the project completion is efficient in terms of time and cost and it achieves work efficiency, both human and equipment (Badri, 1997). Resource needs for each project activity may be different, so there is a possibility that resource fluctuation occurs. This need fluctuation will affect the budget because there is a moment when resources are not empowered while the costs remain out, in which it is called fixed cost.

In the construction industry, the provisions regarding cost, quality, and timing of the construction work completion are bound within the contract and are set before construction work is realized. As it is known, the completion time needed for the construction work process is always included in the contract document as it will have an important effect on the value of the auction and the financing of its own work. Uncontrolled timing of the construction work will cause the owner to have difficulty in finishing the work of a project, as well as the contractor may incur a cost loss so that the contractor in this case should always try to control the execution time as outlined in the work plan which has been determined,in the process of construction work without neglecting quality control. Time, cost, and quality are inseparable unity. The series in construction activities are sequential and interrelated. In planning a project, a decision maker is often confronted with an option in establishing appropriate resources, such as the number of labor, equipment, method, and technology to realize a construction project activity (Morel et al, 2001).

Each selection of defined activities will lead to time, cost, and quality of a project activity (Coulter, 2004). For construction projects in general, the quality is an element that must be maintained in order to always be in accordance with the planning, whereas if retardation in the execution of the project occurs or because of the request of the owner/project owner to shorten the execution time, it is necessary to accelerate the project execution time, (Williams, 1995). This study specifically discusses the realization of project management on the basis of time acceleration and cost savings on Implementation of Road Improvement Activity in Samarinda-Anggana, East Kalimantan Province. Based on data obtained from East Kalimantan Provincial Planning Office, there are several projects that 
have retarded the implementation period started from the Road Enhancement Pack to the Road Maintenance Package. From this experience, it is necessary to have an appropriate plan, which in this case, depends on the Implementation Method used.

The factors that experience or cause retardation are divided into two parts: 1) technical factors, which are directly related to the implementation of activities. The elements included in this technical factor are as follows: the quality and experience of on-site labor, the availability of on-site equipment, the complexity of the work, the availability of materials at the site, the number of labor in an activity, inter-activity relation, the presence of concerted work, 2) Non-technical factors are factors that include technical issues such as: weather, project location, inter-worker relationship, perpetrator leadership style (Daniels et al, 1999).

In this Samarinda-Anggana Road Improvement Project, there are two main areas of work: Stone Installation Work with mortar and mortar concrete road hardening work. In estimating the time and cost of a project, it is necessary to accelerate the process. Acceleration is usually done to optimize the duration of existing activities and minimize risk but still get optimal results, (Azhar, 2011). One of the ways to achieve time and cost efficiency is by using the method of "Fast Track" with modification of CPM model scheduling on the activities of the critical path. By using this method, it is expected to optimize as well as save time and cost on the improving road project in Samarinda - Anggana.

Based on the description on the background, the present research problems are as follows: 1) how long time duration needed by accelerating the activities that are in the critical path on the project work network?, 2) how is the total cost after Fast Track?, 3) how much the difference of time before and after doing Fast Track?. From these problems, this research aims at: 1) Determining the optimal result with the Fast Track process in the project, 2) Determining the cost plan for the time acceleration, 3) Calculating the difference of the optimal time acceleration of the completion of the road improvement project and the cost by doing acceleration.

\section{METHODS OF RESEARCH}

This research is supported by fast track method. Fast track method is a method of acceleration in development by performing activities in parallel or overlap with faster implementation time and more efficient cost, (Kehlet and Wilmore, 2005). The steps of conducting this research are as follows:

1. Identify the activities involved in the project;

2. Identify the interdependence relationship between activities within the project;

3. Determine the time needed;

4. Build project work network;

5. Determine the critical path;

6. Accelerate with Fast Track on critical paths and have long duration. Fast Track analysis steps are as follows (Tjaturono and Mochtar, 2009):

- Logic activity on the critical path is applied to the principle of parallel system or completion of one activity with another activity.

- Logic activity in the relationship between activities must be rational with empirical conditions and use productivity rill.

- Thoroughly consider the volume, timing of resources, and productivity available on critical path activities.

- Do a Fast Track on a critical path only, especially on activities that have the longest duration.

7. Determine the time that will be accelerated and perform the desired acceleration to speed up the execution time with Fast Track, (Pena-Mora and Li, 2001):

- Determine the critical path on the CPM model, which activity is with the longest time;

- How long it takes to accelerate;

- How much time is possible on other critical trajectory activities; 
- Further acceleration can be done if the above acceleration time still cannot overcome the expected time delay;

- Get a network model with CPM method that has been in Fast Track. so that the goal of time acceleration is obtained;

- Doing Fast Track on activities that pass through critical path, this is done repeatedly until several phases and reach saturation time that is until there is no activity that can be done using Fast Track, calculate time obtained after Fast Track with some phases until Saturation time;

- Calculate the cost that can be from the phases that have been accelerated in time;

- Compare time and cost between several Fast Track phases, then compare it to initial time and cost.

\section{RESULTS AND DISCUSSION}

Analysis of CPM (Critical path method) and Fast Track. This study analyzes the acceleration duration for Samarinda-Anggana Road Improvement Projects along $1.95 \mathrm{~km}$, and costs incurred by acceleration using CPM (Critical Path Method) Fast Track. In the process, this method describes the parts of the work in the project and rearranges them in accordance with the logic of dependence, so that afterwards work network for the project can be made. The calculation uses the time and cost data of each parts of the activities which have been arranged in order obtained from the Provincial Public Works Office of East Kalimantan Province's Highways Division. The total project completion according to the contract for 210 calendar days which its work starts from 20 July 2016 - 08 December 2016 with total project cost is Rp.18.344.872.000,00 including Value Added Tax (VAT).

Table 1 - Job description

\begin{tabular}{|c|l|}
\hline No. & \multicolumn{1}{|c|}{ Description } \\
\hline 1 & Mobilization \\
\hline 2 & Excavation for Drainage Drains and Drainage Canals \\
\hline 3 & Pairs of Rocks with Mortar \\
\hline 4 & Ordinary Excavation \\
\hline 5 & Ordinary stockpiling from excavation sources \\
\hline 6 & Class B Aggregate Footing Layers \\
\hline 7 & Class A Aggregate Footing Layers \\
\hline 8 & Class B Aggregate Footing Layers \\
\hline 9 & Cement Concrete Road Pavement \\
\hline 10 & Footing Layers under Lean Mix Concrete \\
\hline
\end{tabular}

Time Schedule Analysis. From the Time Schedule table that has been made by the contractor, it can be concluded as follows: time Schedule made in the form of work recapitulation and not detail in accordance with the activity dependency; distribution of percentages per week is based on estimation only; the critical activity is unknown which its duration should still be accelerated.

Table 2 - Job description

\begin{tabular}{|l|l|l|l|}
\hline No. & \multicolumn{1}{|c|}{ Job description } & Activity & Duration \\
\hline 1 & Mobilization & A & 24 \\
\hline 2 & Excavation for Drainage Drains and Drainage Canals & B & 70 \\
\hline 3 & Pairs of Rocks with Mortar & C & 94 \\
\hline 4 & Ordinary Excavation & D & 46 \\
\hline 5 & Ordinary stockpiling from excavation sources & $\mathrm{E}$ & 70 \\
\hline 6 & Class B Aggregate Footing Layers & $\mathrm{F}$ & 82 \\
\hline 7 & Class A Aggregate Footing Layers & $\mathrm{G}$ & 70 \\
\hline 8 & Class B Aggregate Footing Layers & $\mathrm{H}$ & 70 \\
\hline 9 & Cement Concrete Road Pavement & $\mathrm{I}$ & 94 \\
\hline 10 & Footing Layers under Lean Mix Concrete & $\mathrm{J}$ & 82 \\
\hline
\end{tabular}


Activity Type Grouping. In order to be more efficient and more optimal in arranging the project work network, it is necessary to group similar or cognate works and to combine the volume of each activity by equalizing the volume, (Stevenson and Hojati, 2007). The principle of equality lies in the ratio of the lowest unit costs and and the biggest unit cost multiple with the work type volume of Samarinda - Anggana road improvement project which consist of:

Table 3 - Currency Works Types of Public Works

\begin{tabular}{|c|l|c|c|c|c|}
\hline No. & \multicolumn{1}{|c|}{ Description } & Unit & Volume & Unit Price (Rp) & $\begin{array}{c}\text { Total Unit Price } \\
(\mathrm{Rp})\end{array}$ \\
\hline 1 & Mobilization & Ls & 1,000 & $205.225 .000,00$ & $205.225 .000,00$ \\
\hline 2 & $\begin{array}{l}\text { Excavation for Drainage Drains and } \\
\text { Drainage Canals }\end{array}$ & $\mathrm{m} 3$ & $1.372,49$ & $86.308,37$ & $118.457 .206,45$ \\
\hline 3 & Pairs of Rocks with Mortar & $\mathrm{m} 3$ & 636,975 & $835.743,65$ & $532.347 .813,48$ \\
\hline 4 & Ordinary Excavation & $\mathrm{m} 3$ & 387,266 & $77.120,63$ & $29.866 .199,23$ \\
\hline 5 & $\begin{array}{l}\text { Ordinary stockpiling from excavation } \\
\text { sources }\end{array}$ & $\mathrm{m} 3$ & $1.657,971$ & $143.893,44$ & $238.571 .139,99$ \\
\hline 6 & Class B Aggregate Footing Layers & $\mathrm{m} 3$ & 405,349 & $678.884,53$ & $275.185 .164,81$ \\
\hline 7 & Class A Aggregate Footing Layers & $\mathrm{m} 3$ & 387,266 & $839.164,89$ & $324.980 .029,67$ \\
\hline 8 & Class B Aggregate Footing Layers & $\mathrm{m} 3$ & $4.368,000$ & $2.671 .542,16$ & $11.669 .296 .155,13$ \\
\hline 9 & Cement Concrete Road Pavement & $\mathrm{m} 3$ & $1.440,000$ & $2.079 .619,03$ & $2.994 .651 .403,08$ \\
\hline 10 & Footing Layers under Lean Mix Concrete & $\mathrm{m} 3$ & 159,00 & $181.4947,62$ & $28.857 .6671,58$ \\
\hline
\end{tabular}

Calculating Volume Per Activity Type. Volume calculation is done at the same time as the activity type equalization. Volume used in the next calculation is the volume of the equalization result, volume calculation is based on the distance of the road improvement.

Arranging Inter-activity Dependence. In determining the relevance or dependence of an activity, it must be in accordance with the method of work completion, so that logical technique is needed in the preparation.

Table 4 - Logic of Interdependence between activities

\begin{tabular}{|c|l|c|c|c|}
\hline No. & \multicolumn{1}{|c|}{ Job description } & Activity & Predecessor & Followers \\
\hline 1 & Mobilization & $\mathrm{A}$ & - & $\mathrm{B}, \mathrm{C}, \mathrm{F}, \mathrm{I}$ \\
\hline 2 & Excavation for Drainage Drains and Drainage Canals & $\mathrm{B}$ & $\mathrm{A}$ & $\mathrm{D}$ \\
\hline 3 & Pairs of Rocks with Mortar & $\mathrm{C}$ & $\mathrm{A}$ & $\mathrm{G}$ \\
\hline 4 & Ordinary Excavation & $\mathrm{D}$ & $\mathrm{B}$ & $\mathrm{E}$ \\
\hline 5 & Ordinary stockpiling from excavation sources & $\mathrm{E}$ & $\mathrm{D}$ & $\mathrm{A}_{2}$ \\
\hline 6 & Class B Aggregate Footing Layers & $\mathrm{F}$ & $\mathrm{A}$ & $\mathrm{H}$ \\
\hline 7 & Class A Aggregate Footing Layers & $\mathrm{G}$ & $\mathrm{C}$ & $\mathrm{E}$ \\
\hline 8 & Class B Aggregate Footing Layers & $\mathrm{H}$ & $\mathrm{F}$ & $\mathrm{G}$ \\
\hline 9 & Cement Concrete Road Pavement & $\mathrm{I}$ & $\mathrm{A}$ & $\mathrm{J}$ \\
\hline 10 & Footing Layers under Lean Mix Concrete & $\mathrm{J}$ & $\mathrm{I}$ & $\mathrm{E}$ \\
\hline
\end{tabular}

Critical Path Determination. Determination of critical path for Samarinda-Anggana Road Improvement Project along $1,95 \mathrm{Km}$ is obtained by using method of CPM (Critical Path Method). To facilitate work network project, list of activities will be made first that precede other activities presented in the form of tables that contain predecessor activities in the sequence of dependence logic. The use of predecessor activity data obtained network for Samarinda-Anggana Road Improvement Project along $1.95 \mathrm{Km}$ which is frolic. Having obtained the numbers of both back and forth calculation, then critical path of the network can be determined, the critical path starting from the initial circle (start circle) to the final circle (finish circle) in which the values of total float (TF) and free (float) from the activities are equal to zero (0). Furthermore, the network of Samarinda-Anggana Road Improvement activities and the acceleration of its critical trajectory are determined.

Fast Track Network Modeling. After the normal time network is arranged in accordance with the activity plan, it is known that the project execution time exceeds the required time of 21 days, while the RAB time is 7 months. So, it needs network modeling to accelerate the work activity using fast track method. Fast track modeling is performed on critical trajectory 
activities that have a long duration of work and is performed until such activity is no longer possible to accelerate.

Table 5 - Time Acceleration in Critical Path Activity

\begin{tabular}{|c|c|c|c|c|c|c|}
\hline No. & Job description & Activity & Duration & $\begin{array}{c}\text { Acceleration } \\
\text { Phase } 1 \text { (days) }\end{array}$ & $\begin{array}{c}\text { Acceleration } \\
\text { Phase } 2 \text { (days) }\end{array}$ & $\begin{array}{c}\text { Acceleration } \\
\text { Phase } 3 \text { (days) }\end{array}$ \\
\hline 1 & Mobilization & $A$ & 24 & 3 & 4 & 6 \\
\hline II & $\begin{array}{c}\text { Excavation for Drainage } \\
\text { Drains and Drainage } \\
\text { Canals }\end{array}$ & B & 70 & 8 & 13 & 16 \\
\hline III & $\begin{array}{l}\text { Pairs of Rocks with } \\
\text { Mortar }\end{array}$ & C & 94 & 0 & 0 & 0 \\
\hline IV & Ordinary Excavation & $\mathrm{D}$ & 46 & 5 & 9 & 11 \\
\hline V & $\begin{array}{l}\text { Ordinary stockpiling } \\
\text { from excavation } \\
\text { sources }\end{array}$ & E & 70 & 8 & 13 & 16 \\
\hline VI & $\begin{array}{l}\text { Class B Aggregate } \\
\text { Footing Layers }\end{array}$ & $\mathrm{F}$ & 82 & 0 & 0 & 0 \\
\hline VII & $\begin{array}{l}\text { Class A Aggregate } \\
\text { Footing Layers }\end{array}$ & G & 70 & 0 & 0 & 0 \\
\hline VIII & $\begin{array}{l}\text { Class B Aggregate } \\
\text { Footing Layers }\end{array}$ & $\mathrm{H}$ & 70 & 0 & 0 & 0 \\
\hline IX & $\begin{array}{c}\text { Cement Concrete Road } \\
\text { Pavement }\end{array}$ & 1 & 94 & 0 & 0 & 0 \\
\hline$x$ & $\begin{array}{l}\text { Footing Layers under } \\
\text { Lean Mix Concrete }\end{array}$ & $\mathrm{J}$ & 82 & 0 & 0 & 0 \\
\hline
\end{tabular}

Table 6 - Duration of Each Acceleration Phase

\begin{tabular}{|c|c|c|c|c|c|c|}
\hline No. & Job description & Activity & Duration & $\begin{array}{c}\text { Fast Track } \\
1\end{array}$ & $\begin{array}{c}\text { Fast Track } \\
2\end{array}$ & $\begin{array}{c}\text { Fast Track } \\
3\end{array}$ \\
\hline I & Mobilization & A & 24 & 3 & 4 & 6 \\
\hline II & $\begin{array}{c}\text { Excavation for Drainage Drains and } \\
\text { Drainage Canals }\end{array}$ & B & 70 & 8 & 13 & 16 \\
\hline III & Pairs of Rocks with Mortar & C & 94 & 11 & 17 & 22 \\
\hline IV & Ordinary Excavation & D & 46 & 5 & 9 & 11 \\
\hline V & Ordinary stockpiling from excavation \\
sources & $\mathrm{E}$ & 70 & 8 & 13 & 16 \\
\hline VI & Class B Aggregate Footing Layers & F & 82 & 9 & 15 & 19 \\
\hline VII & Class A Aggregate Footing Layers & G & 70 & 8 & 13 & 16 \\
\hline VIII & Class B Aggregate Footing Layers & H & 70 & 8 & 13 & 16 \\
\hline IX & Cement Concrete Road Pavement & I & 94 & 11 & 17 & 22 \\
\hline X & Footing Layers under Lean Mix Concrete & J & 82 & 9 & 15 & 19 \\
\hline
\end{tabular}

Project Cost Calculation After Fast Track. Based on the project work plan, the cost is as much Rp.16.677.156.783,43. Implementation of critical activity is done in parallel. There is no increase in the number of labor and the cost of each activity, both the activity on the critical path and the non-critical activity. It is also same as on the use of materials. The use of materials is in line with normal use including the price of the materials. is There is no change in the cost of labor in accordance with the the moment of the research is done. The non-fixed cost is the operational cost incurred by the contractor as much $5 \%$ of the fixed cost of realizing Samarinda-Anggana Road Improvement project. Also, with Fast Track CPM method, it can be seen the results of the acceleration process in this analysis which are optimal cost and time.

The difference is in the indirect costs because the development duration becomes shorter than the planned project duration of 210 days to be 186, 171, and 161 calendar days. Thus, the total cost after Fast Track, it can be concluded that there is indirect cost savings in Fast Track phase 1, that is equal to $0,57 \%$ from normal cost. Then, at the Fast Track phase 
2 , there is a cost optimization of $0.93 \%$ of normal cost. Furthermore, at the Fast Track phase 3 , there is a cost optimization of $1.17 \%$ of the normal cost. So that, Fast Track phase 2 can be selected from the results of cost and optimal time with Fast Track method because besides time has optimal result which leads to indirect costs decreased but it does not also add budget cost.

Table 7 - Comparison of Normal Project Cost after Fast Track

\begin{tabular}{|l|l|l|l|l|}
\hline \multirow{2}{*}{\multicolumn{1}{|c|}{ Information }} & \multicolumn{3}{|c|}{ Actual productivity } \\
\cline { 2 - 5 } & Normal duration & Fast track phase 1 & Fast track phase 2 & Fast track phase 3 \\
\hline Time / Duration (days) & 210 & 186 & 171 & 161 \\
\hline Project Budget (Rp) & Rp.16.677.156.783,43 & Rp.16.677.156.783,43 & Rp.16.677.156.783,43 & Rp.16.677.156.783,43 \\
\hline Fixed Cost (Rp) & Rp.15.843.298.944,5 & Rp.15.843.298.944,25 & Rp.15.843.298.944,25 & Rp.15.843.298.944,25 \\
\hline Variable cost & Rp.833.857.839,17 & Rp.738.559.800,41 & Rp.678.998.526,18 & Rp.639.291.010,03 \\
\hline Total Cost (Rp) & Rp.16.677.156.783,43 & Rp.16.581.858.744,66 & Rp.16.522.297.470,44 & Rp.16.482.589.954,29 \\
\hline Savings (Rp) & Rp - & Rp.95.298.038,76 & Rp.154.859.312,99 & Rp.194.566.829,14 \\
\hline Savings (\%) & 0,00 & 0,57 & 0,93 & 1,17 \\
\hline
\end{tabular}

Table 8 - Fastest Time Output with Cost Savings

\begin{tabular}{|c|c|c|c|c|c|}
\hline No. & Overtime & Time & Acceleration & Total Cost & Cost Savings \\
\hline 1 & Normal & 3005 & 210 & - & Rp18,344,872,461.77 \\
\hline 2 & 1 Hour & 3005 & 186 & 24 & Rp $17,018,427,461.77$ \\
\hline 3 & 2 Hours & 3005 & 171 & 39 & Rp $17,050,625,461.77$ \\
\hline
\end{tabular}

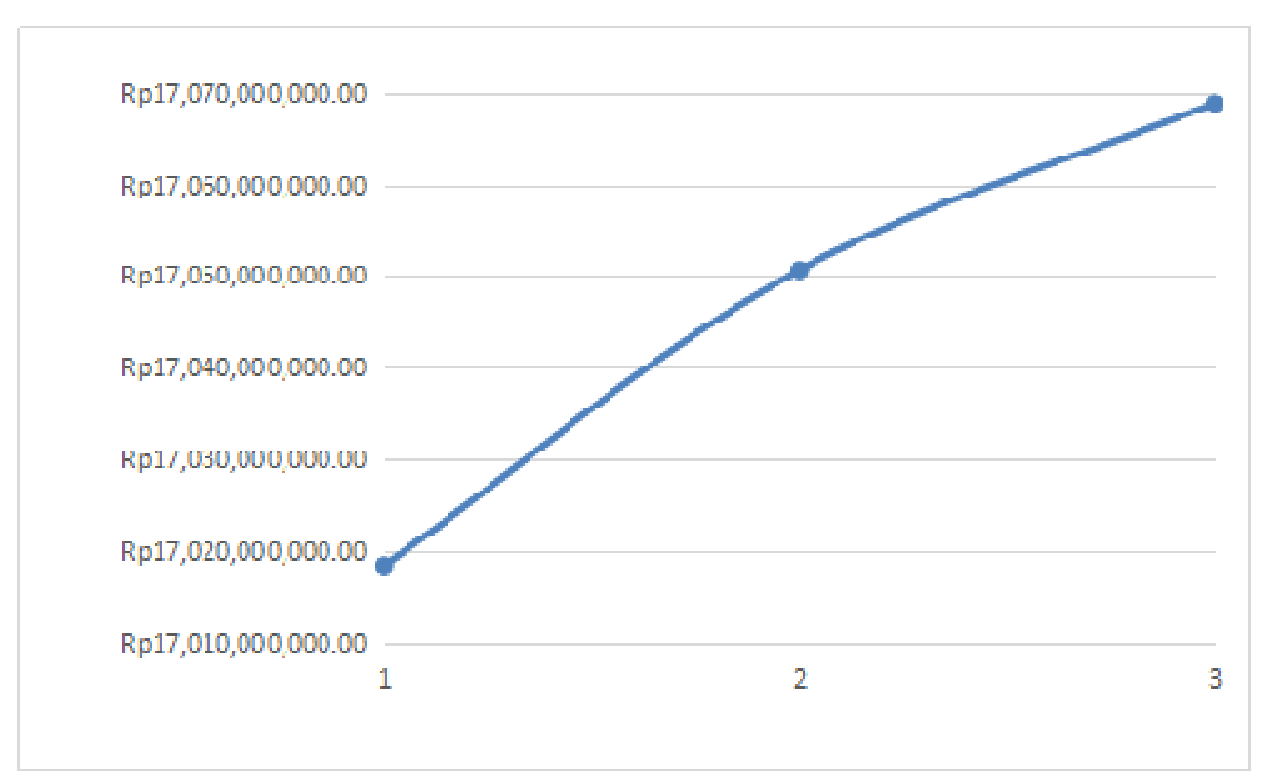

Figure 1 - Relationship between Time and Cost towards Total Project Cost

Based on the above drawings of the project completion time, an effective project completion time with the optimal project cost is chosen. In this case, it is very beneficial in terms of time and cost over the acceleration of some activities obtained on 2-hour overtime alternatives in which all activities are included into critical paths on the 2-hour overtime alternative

\section{CONCLUSION}

From the calculation result of the project duration using fast track method on Samarinda - Anggana Road Improvement Project Implementation in the area of Kutai Lama, the following conclusions are obtained: 
Samarinda - Anggana Road improvement project is calculated with CPM model with normal duration in the contract time of 210 days, so the project needs to be accelerated by Fast Track method that produces acceleration duration to 171 days.

Optimal costs incurred at normal duration or the project budget plan is Rp.16.677.156.783,43 and costs generated after Fast Track method is Rp. 16.522.297.470,44.

The difference in duration between normal time and after fast track is 39 days. While, the difference between the cost of normal time and after using the Fast Track is Rp.154.859.312,99, hence, it can be concluded that savings of $0.93, \%$ of the normal cost.

\section{REFERENCES}

1. Akbar. (2002). Manajemen Kegiatan proyek. Jurnal manajemen, Surabaya.

2. Badri, S. (1997). Dasar-Dasar Network Planning. Jakarta: PT. Rika Cipta.

3. Davidson, J. (2002). Penuntun 10 Menit Manajemen Proyek, Terjemahan dari Ten Minute Guide Project Management, oleh Sisnuhadi. Yogyakarta: Andi.

4. Hellriegel, D., \& Slocum, J. W. (2006). Management des organisations. De Boeck Supérieur.

5. Tjaturono, T., \& Mochtar, I. B. (2009). Pengembangan Metode Fast-Track untuk Mereduksi Waktu dan Biaya Pelaksanaan Proyek Studi Kasus Rumah Menengah di Malang, Jawa Timur. MEDIA KOMUNIKASI TEKNIK SIPIL, 17(1), 39-54.

6. Kehlet, H. (2005). Fast-track surgery. British Journal of Surgery, 92(1), 3-4.

7. Pena-Mora, F., \& Li, M. (2001). Dynamic planning and control methodology for design/build fast-track construction projects. Journal of construction engineering and management, 127(1), 1-17.

8. Williams, G. V. (1995). Fast track pros and cons: Considerations for industrial projects. Journal of Management in Engineering, 11(5), 24-32.

9. Stevenson, W. J., \& Hojati, M. (2007). Operations management (Vol. 8). Boston: McGraw-Hill//rwin.

10. Azhar, S. (2011). Building information modeling (BIM): Trends, benefits, risks, and challenges for the AEC industry. Leadership and management in engineering, 11(3), 241252.

11. Morel, J. C., Mesbah, A., Oggero, M., \& Walker, P. (2001). Building houses with local materials: means to drastically reduce the environmental impact of construction. Building and Environment, 36(10), 1119-1126.

12. Söderlund, J. (2004). Building theories of project management: past research, questions for the future. International journal of project management, 22(3), 183-191.

13. Daniels, G., Ellis, D. R., \& Stockton, W. R. (1999). Techniques for manually estimating road user costs associated with construction projects (Vol. 3). Texas,, USA: Texas Transportation Institute.

14. Carayannis, E. G., Kwak, Y. H., \& Anbari, F. T. (Eds.). (2005). The story of managing projects: an interdisciplinary approach. Greenwood Publishing Group.

15. Coulter, E. D. (2004). Setting forest road maintenance and upgrade priorities based on environmental effects and expert judgment (Doctoral dissertation).

16. Chou, J. S., Peng, M., Persad, K., \& O'Connor, J. (2006). Quantity-based approach to preliminary cost estimates for highway projects. Transportation Research Record: Journal of the Transportation Research Board, (1946), 22-30.

17. Zhu, Y., Ahmad, I., \& Wang, L. (2009). Estimating work zone road user cost for alternative contracting methods in highway construction projects. Journal of Construction Engineering and Management, 135(7), 601-608.

(C) 2017 by the authors. Licensee RJOAS, Orel, Russia. This article is an open access article distributed under the terms and conditions of the Creative Commons Attribution (CC BY) license: http://creativecommons.org/licenses/by/4.0/ 